\title{
THE INSCRIPTIONS OF THE SECOND PYLON OF RAMESSES II AT ABYDOS
}

By

\author{
Ahmed Amin Selim \\ Professor at faculty of Arts, Alexandria University, Cairo, Egypt
}

\begin{abstract}
[AR]

نقوش الصرح الثانى للملك رعمسيس الثانى فى أبيدوس:

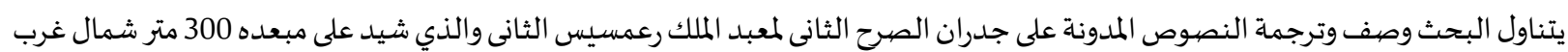

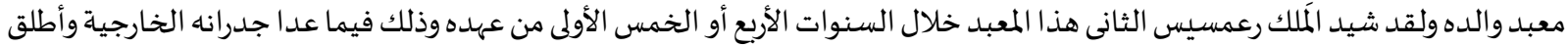

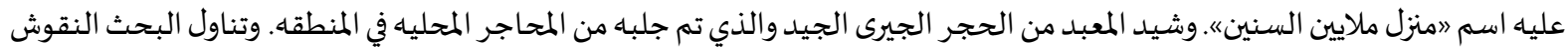

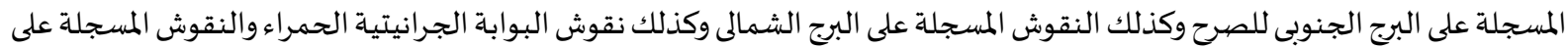

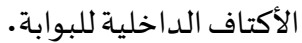

[EN] This paper deals with the inscriptions of the second pylon of king Ramesses II at Abydos. He built this temple to sanctify the three principal deities of Abydos: Osiris, Isis, and Horus, and to deify himself in it, and to be a house of a million years in which to be worshipped with religious rituals performed for him after his death.

KeYWorDs: Ramesses II, Abydos, Temple, Pylon. 


\section{I- INTRODUCTION}

Ramesses II built his temple at Abydos around 300 meters northwest of his father's temple. Nearly all the construction and decoration of the temple occurred within the first four to five years of Ramesses II's reign except the outside walls. Its name has been mentioned as Hwt-Rcmsi-sw hnmt $m T_{3}$-wr «House of Ramesses is joined to the Abydos Nome». This name is sometimes replaced by or modified with the term $h w t-h h w-n t-r n p w t$ «the House of Millions of years» ${ }^{1}$.

The temple was mainly built of fine white limestone which was cut from the local quarries. It mentioned in dedication inscriptions ${ }^{2}$ that many other kinds of stone were used in building such as black and red granite, alabaster, Nubian sandstone, and fine red quartzsite sandstone which was brought from Gebel al-Ahmer ['Abbasslya].

The temple is rectangular in plan. It is consists of an outer court, including its pylon, an inner court with a granite doorway to the pylon, two hypostyle halls, and a sanctuary, with subsidiary shrines and chambers [FIGURE $1 /$ a] ${ }^{3}$.

\section{II- DESCRIPTION OF THE SECOND PYLON}

It ismost probable that the temple of Ramesses II at Abydos had only one pylon and one court when it was first built. Later in the king's reign, an outer court and pylon were added. Consequently, what today we call the second pylon is, in reality, the original outer pylon. [FIGURE 1 / b] This can be proved by the following facts:

1- The plan of this temple, with one pylon and one court, is a complete whole.

2- The so-called second pylon has four rectangular grooves in its outer face for the erection of the wooden masts, from which floated long, coloured streamers. These grooves and wooden masts are a feature of outer pylons but do not occur on inner pylons which were planned in that manner 5 .

3- The ends of the eastern face of the present second pylon had their surfaces dressed smooth and sculptured. Clearly, it was not then intended that the walls of an outer court should be built onto them ${ }^{6}$.

The second pylon measures about $39.0 \mathrm{~m}$. wide and is $5.50 \mathrm{~m}$. thick. Its central gateway is a magnificent monument of finely sculpted red granite, called ${ }^{7}$

\footnotetext{
${ }^{1}$ GOELET \& ISKANDER 2012: 143.

2ZAYED 1988: 114.

${ }^{3}$ MARIETTE 1867: Pls. 55-61; 100-109; MARIETTE 1880: vol.2: Pls.2-20; 2-25; LePSiUs 1897: 66 [middle]; LEFEBVRE 1906: 213; PORTER\&MOSS 1976: vol.4,32.

${ }^{4}$ SELIM 1991-1992:2-25

${ }^{5}$ See for example: the pylons of Sety I at Abydos, where the outer pylon has grooves, but the second pylon, has only statue-niches, and no grooves for masts. MARIETTE 1869: vol.1; CAPART 1912; O'CONNER 2009: FiGs. 16,47.

${ }^{6}$ The walls of an additional court were built out directly from this smooth surface, with no attempt to interlock the end blocks with the masonry of the original pylon.

${ }^{7}$ MARIETTE 1880: 8.
} 


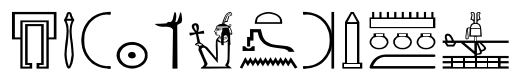 \\ $\mathrm{Sb}_{3}{ }^{c} 3\left(\mathrm{Wsr} \mathrm{m}_{3}{ }^{c} t \mathrm{R}^{c} \operatorname{stp} n \mathrm{R}^{c}\right) \mathrm{mn} \mathrm{mnw}_{\mathrm{w}} \mathrm{T}_{3}-\mathrm{wr}$}

«The great gateway of Weser-maât-Râ-Setep-en-Râ- who established monuments in the Abydos Nome» ${ }^{8}$.

The four outer corners of the towers are adorned with torus mouldings, measuring about $0.30 \mathrm{~m}$. in diameter [FIGURE 2].

\section{1- The Southern Tower}

The Southern Tower of the second pylon is preserved to a height of about $3.0 \mathrm{~m}$, except for a granite jamb of the doorway which is about $4,30 \mathrm{~m}$. high. The outer [eastern] face was adorned with scenes in sunken relief, but of these very little remains.

At the southern endthe first $1.58 \mathrm{~m}$ is blank, the sculpture having been erased when the wall of the outer court was built. After this, on the upper part is a frieze consisting of eighteen crenellated ovals, each containing the names of southern countries which Ramesses II claims to have conquered. Each oval is surmounted by the bust of a southern prisoner, with his arms bound behind his back, and are linked together by a cord passing around the neck of each prisoner [FIGURE 31 ${ }^{9}$. The names in the cartouches - fortresses can be read after restorations from a shortlist on the southern wall of the entrance as follows ${ }^{10}: \vec{l}$

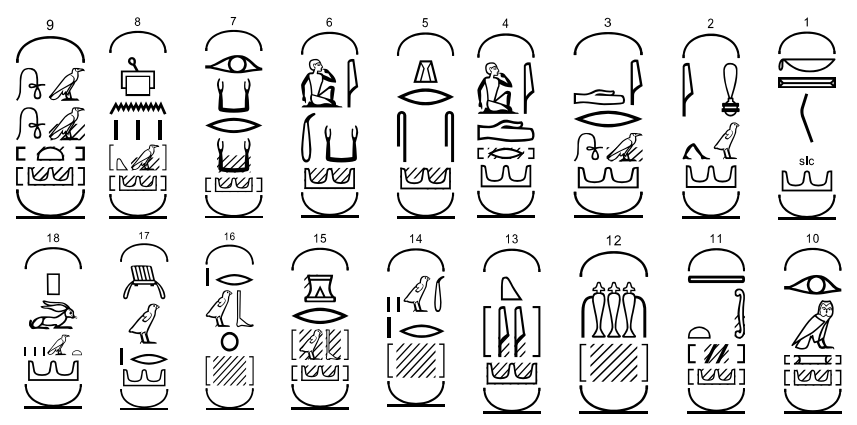

1- Kš: Nubia ${ }^{11}$.

2- Miiw: Probably the extreme south of the region known to the Egyptians ${ }^{12}$. It may be identified with Kerma ${ }^{13}$. It was first mentioned in the list of Tuthmosis III at Karnak ${ }^{14}$. 3-Idrw3: Probably in the vicinity of Miiw ${ }^{15 .}$

\footnotetext{
${ }^{8}$ BRUGSCH 1862: PL.12; BREASTED 1906: § 528.

${ }^{9}$ MARIETTE1880: vol .2 , PL. 3 .

${ }^{10}$ MARIETTE1880: vol .2 , Pl.3 , 8-9; BREASTED 1906: § 139; KiTCHEN 1999:192.

11 KeES 1961: 308; ZeIBELIUS 1972: 165-169.

${ }^{12}$ GAUTHIER 1926: vol.3, 11.

13 ZEIBELIUS 1972: 120.

14 SETHE 1961:796, №.4; KITCHEN 1999: 104.

${ }^{15}$ MARIETTE 1880: 9, [3].
} 
4- Idr: A region in Africa, perhaps the Greek Adulis, and the extreme south of the Negro peoples know to the Egyptians ${ }^{16}$. Adulis was a port of Aksum in the Red Sea ${ }^{17}$.

5- Grss: Probably at the extreme limit of the land of Kusk from South ${ }^{18}$, and it was identified by Mariette with Kassla ${ }^{19}$, at the bank of Atbara ${ }^{20}$. It was mentioned in many lists, such as: the list of Tuthmosis III at Karnak, the list of Amenhotep III at Soleb, and the list of Taharqa.

6- Ik3 Wti: Ikuta or Akuta. The Kuban, in front of Dakkeh in lower Nubia ${ }^{21}$. It has no older equivalent, and it may be an abbreviated spelling of Akuati, a name actually current under Ramesses I such as in the Stelae of Ramesses II at Kuban, the list of Ramesses II at Karnak, list of Taharqa, and it also appears on a statue in the entrance of the temple of Ramesses II at Karnak.

7- Irk3 $r k_{3}$ : A Negro tribe of Ethiopia ${ }^{22}$. It has appeared in the list of Taharqa at Karnak,

8- $S_{3} n$ wks: A Negro people of upper Sudan, It was also mentioned in the list of Taharqa at Karnak ${ }^{23}$.

9- $W_{3}$ w3.t: It was contained by ancient Egyptians, all the land which lies between the Nile and red-sea, from Aswan to Korosko ${ }^{24}$.

10- Irm: Country on the red sea coast, which Brugsch identified with the Blemmyes ${ }^{25}$.

11- T3-Sti: The northern part of the Nubian land ${ }^{26}$, in the first Nome of Upper Egypt ${ }^{27}$.

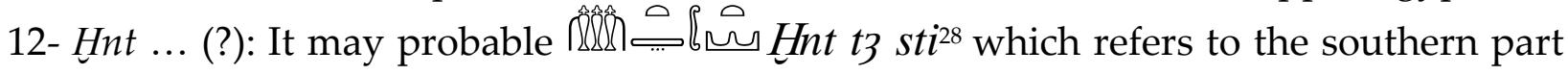
of theNubian land ${ }^{29}$.

13-Krii: A Sudanese locality, probably the modern village El-Kurru ${ }^{30}$. It's marking the extreme southern limited of the Egyptian empire during the $18^{\text {th }}-19^{\text {th }}$ Dynasties.

14- Tw rw ... (?): It may be Tw rwrk which is mentioned in the list of Tuthmosis III at Karnak, №.14 $14^{31}$ and in the list of Sethos I at Karnak. It lies in south Egypt, identified with Tomkins, north of Orma ${ }^{32}$.

15- Gr (bw)?: It lies between the Nile and the Red Sea from Abu Hamed to the fifth cataract $^{33}$.

\footnotetext{
${ }^{16}$ GAUTHIER 1925: vol.1, 114,128.

${ }^{17}$ BAKER 1998: 171.

${ }^{18}$ GAUTHIER 1928: vol.5, 214.

${ }^{19}$ MARIETTE 1880: 9 [5].

${ }^{20}$ ZiBELIUS 1972: 171.

${ }^{21}$ It was a notorious gold-bearing, but waterless desert -region south-east from Quban [ancient Baqi].

GAUTHIER 1925: vol.1,: 110; KEES 1961: 322; ZIBELIUS 1972: 95-96; KITCHEN 1999:104.

${ }^{22}$ GAUTHIER 1925: vol.1, 97.

${ }^{23}$ GAUTHIER 1928: vols.5- 6 .

${ }^{24}$ GAUTHIER 1925: vol.1, 173-174.

${ }^{25}$ Gardiner said that: «I am much more doubtful». GAUTHIER 1925: I: 93; GARDINER 1947: 209.

${ }^{26}$ GARDINER 1947: 11.2; GAUTHIER 1925: 31-32.

${ }^{27}$ MONTET 1961: 14.

${ }^{28}$ It may be [hnt-hfn- nfr ?]. KITCHEN 1979: 57.

${ }^{29}$ GAUTHIER 1927: IV, 184.

30 GRIFFITH 1917: 27; ZIBELIUS 1972: 162-163.

${ }^{31}$ SETHE 1961:797, №.14.

${ }^{32}$ GAUTHIER 1929: vol.4, 41, №.14.
} 


\section{Festschrift of Professor Ali Radwan [1941-2020]}

16- $R_{3} b w$ (?): The Libyan Desert and the Oases (?) $)^{34}$. 17- $3 w r$ : An unidentified region in Africa ${ }^{35}$.

18- Pwn tiw: The people of the region of Punt ${ }^{36}$.

Below this frieze of conquered south peoples are some more scenes and inscriptions. At the extreme southern end ${ }^{37}$ is a damaged representation of Goddess Sefkhet $^{38}$ seated on a throne, facing north ${ }^{39}$. Of her figure, only part of her headdress, her feet, and the lower part of her throne are preserved. In front and above her are seven vertical lines of inscription ${ }^{40}$, which is read: -1

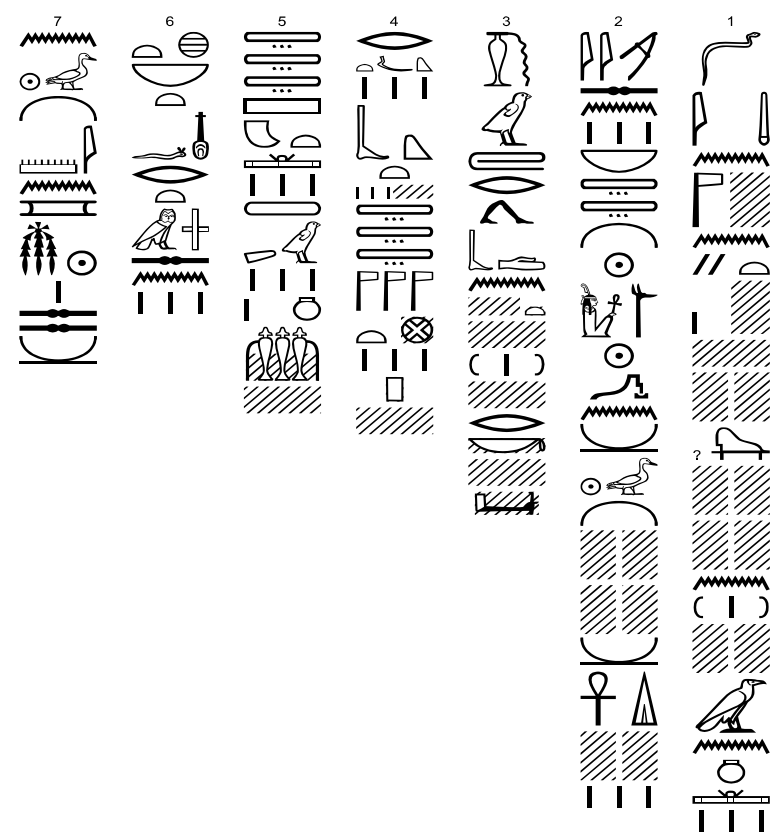

1-Dd $m d w$ in $n t r$ nty [...] wsir (?) $n^{41}[\ldots] n w . w$

2- mri.sn nb t3-wy $\left(W s r-m 3^{c} t-R^{c} s t p-n-R^{c}\right) S_{3} R^{c}[\ldots] d i^{c} n h[\ldots]$

3- kbh.w phr dbn [...] r.k (?) [...]

4-rth.w kbt.w t3.w ntr.w niwwt $p[\ldots]$

5-t3.w št3.w t3.w nw hnt [...]

6-hwt nbwt nfrw.t imy.w.sn

7- $n$ s3- $R^{c}\left(R^{c}-m s i-s w\right.$ mri Imn $)$

33 ZIBELIUS 1972: 170.

${ }^{34}$ GAUTHIER 1926: vol.3: 117. It may (Rbh ?) KITCHEN 1979: 57.

35 GAUTHIER 1925: vol.1, 2.

${ }^{36}$ GAUTHIER 1925: vol.2, 46.

${ }^{37}$ A break of $19.5 \mathrm{~cm}$. The tall signs measure $8.0 \mathrm{~cm}$ high.

38 Sefkhet was the Goddess of writing and temple libraries. She first appears during the reign of Thuthmosis III, and seems little more than a version of Seshat. Her role is to be present at the temple foundation ceremony of «stretching the cord» she also figures among the deities responsible for the writing of the name of the pharaoh on the leaves of the sacred tree. HART 1987:191-192.

${ }^{39}$ PORTER \& MOSS 1976: vol.4: 33.

${ }^{40}$ DARESSY 1899: 8 (middle).

${ }^{41}$ A break of $38.0 \mathrm{~cm}$. 
" (1) Word recitation by the god who is [in Abydos] Wsir (2) beloved of them, the lord of the Two lands ( Weser, maât Râ- Setep-en-Râ), the son of Râ [...] given life [...] (3) libation [...] turn and go round [...] (4) foreign people ${ }^{42}$, lands of Gods, cities of [...] (5) the inaccessible lands, the regions of Khent [ken-nufer (Nabia) ${ }^{43}$ (6) all good things which are in them (7) for the son of Râ, ( Ramesses Mery Amon)».

Below the throne of the Goddess, the surface of the pylon is marked out for an inscription of four horizontal lines. However, these were never completed and were probably made when the decoration of the end of the tower was changed to allow for the building of the wall of the additional court. This horizontal inscription is read as follows: -

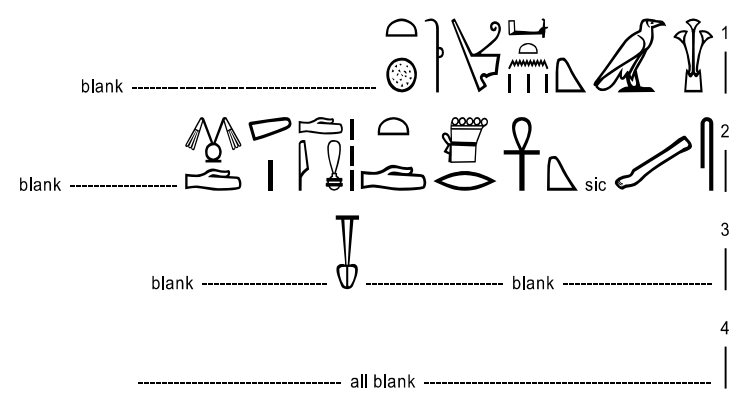

1-h.hk.tn $n$ rnpt $[\ldots]$

2-Skr ${ }^{c} n h \underline{d} \underline{d r t . w}$ dmi dm $\underline{d}[\ldots]$

$$
\begin{gathered}
\text { 3- }[\ldots] \mathrm{sm}_{3} \\
\text { 4- }[\ldots]
\end{gathered}
$$

«(1) You plunders/captures in year ${ }^{44}[\ldots]$ (2) the hands of the colony's captives are united $[\ldots](3)[\ldots]$ united $[\ldots] \gg 4-\ldots$

Between this scene and the first southern groove for the masts was along with the scene, terminating in a horizontal inscription. At the northern end, Ramesses is seated upon a throne [Facing south] in a light pavilion, the roof of which is supported by papyri form columns. The king wears $3 t f$ crown, but his figure is destroyed from the nose downwards. In front of his crown are four short vertical lines of inscription, reading: $\vdash$

\footnotetext{
${ }^{42}$ ERMAN \& GRAPOW (eds.) 1971: vol.2, 460,8.

${ }^{43}$ KITCHEN 1996: 58.

${ }^{44}$ Unfortunately, the regnal year was never completed.
} 


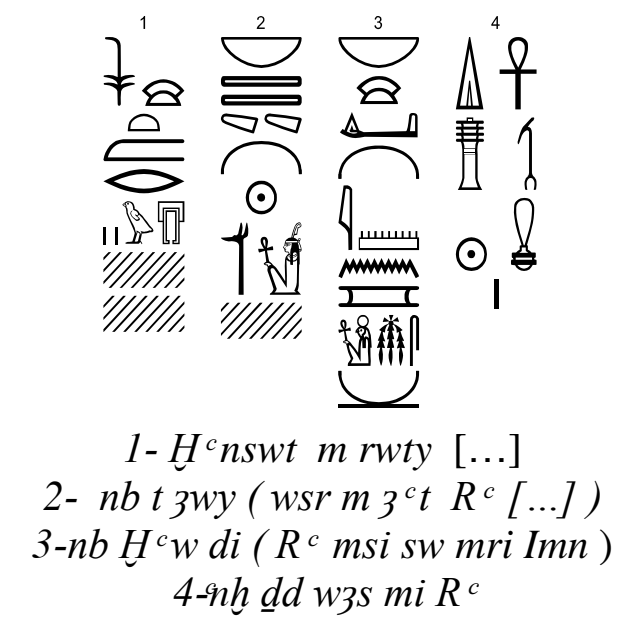

«(1) The king appears in Double Gateway [...] (2) the lord of the two lands ( Wesermaât- Râ [...] (3) the lord of crowns offers, (Ramesses Mery- Amon), (4) given life, stability, prosperity like Râ».

The middle of the scene is destroyed, but at the bottom may be seen the dais upon which the king's throne rests. The center bears a large sign of union $\mathbb{I} s m$, to which two kneeling figures Nile-gods are tying the lily and papyrus. Behind each God, but facing outward, is the figure of a walking lion, executed in a very natural manner. The dais was accented by a flight of six steps, on each of which a small figure of a genius sits enthroned. At the top of the stairs is a damaged inscription reading:

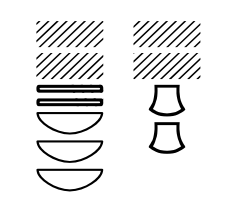

$$
\begin{aligned}
& {[\ldots] \text { tzw } n b w[\ldots] \text { all lands. }} \\
& {[\ldots] \text { nstiw }[\ldots] \text { thrones. }}
\end{aligned}
$$

In front of the pavilion in which the king is seated are tops of three standards. In front of the stairs of the pavilion is a single vertical inscription, reading: $t$

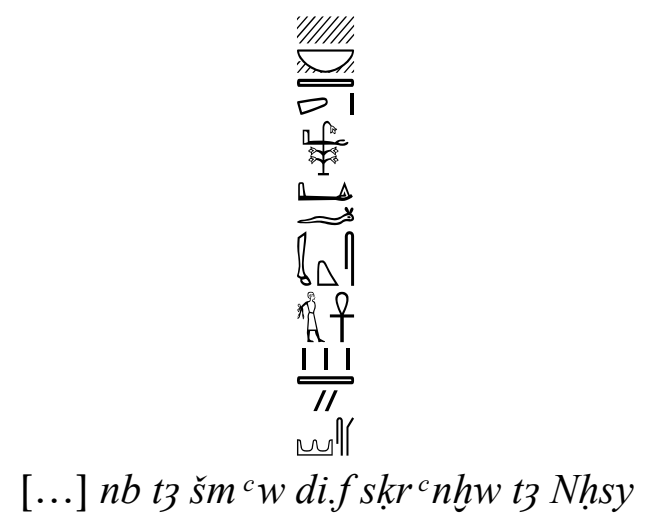

«[...] Lord of the land of Upper Egypt, he gives living prisoners/captives of the land of Nubia». 
Following this inscription comes a God, his head destroyed. At the end of this scene [FIGURE 2] are some traces of a horizontal inscription, the few remaining signs of which read:

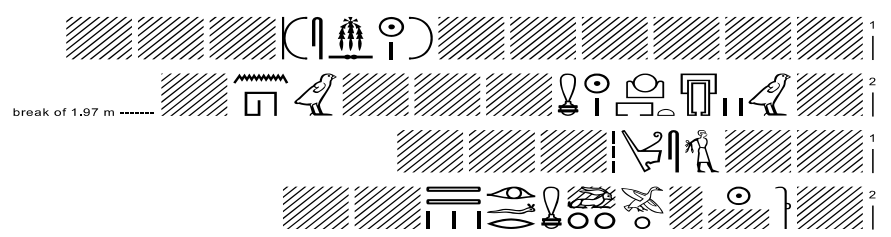

$1-[\ldots \ldots \ldots \ldots . . ..] R^{e} \operatorname{msi} s w[\ldots \ldots \ldots \ldots . .$.

2- [...] rwti 3 ht mi $R^{c}[\ldots]$ wnh $[\ldots][\ldots$

3- sbiw hftyw .s $n$ ?? [...]

(1) $[\ldots . . .$.$] Râmesses [\ldots .$.

4- rnpt [...] p3 wnnwt mi ir.frt $3 w y[\ldots]$

(2) The double gateway of horizon shines like Râ

3- her (s) may be refer to a foreign country like Nubia) captives?

$4-[\ldots]$ the year $[. .$.$] in the exact time (?) «as he made the two lands [\ldots](?) »$

After this group of scenes comes the southernmost of the two grooves for masts of the pylon [FIGURES 2, 5]. This groove measures $1.10 \mathrm{~m}$. wide, and is $0.85 \mathrm{~m}$.deep at its lowest part. On its southern side are two vertical rows of large hieroglyphs, reading [FIGURES 2,4]: -

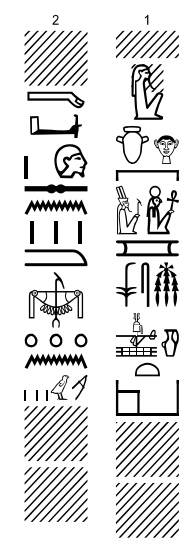

\section{1-[...] hrry-ib ḩwt Rc msi sw mri Imn $\underline{h} n m t$ T3-wr \\ 2-[...] di tpi .sn $m \underline{d}^{c} m n$ mrw [...]}

«(1) [...] who dwells in the House-of-Ramesses-Mery- Amon- who is joined to Abydos

Nome $[\ldots](2)[\ldots]$ offer their taxes of fine gold and meru-wood $\left.[\ldots]^{(45)}\right)_{\text {». }}$

On the northern side of the groove [FIGURES 2,6] are two similar vertical inscriptions, which read: $\vdash$

\footnotetext{
${ }^{45}$ Evidently referring to the masts which once stood in these grooves .
} 


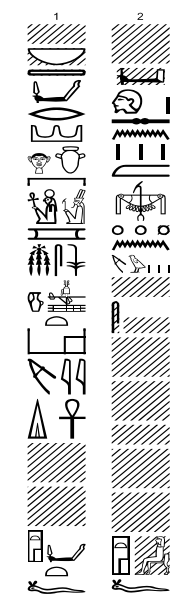

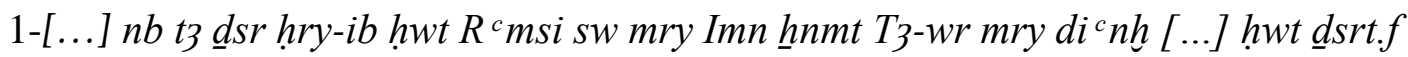
2-[...] di tpi.sn $m \underline{d}^{c} m$ n mrw [...] s [...] hwwt špss.f

" (1) [...] lord of the sacred land, who dwells in the House of Ramesses-Mery-Amonwho is joined to the Abydos Nome», given life [...] his sacred Temple.

(2) [...] offer their taxes of fine gold, and meru-wood [...] his august Temple».

On the short space of the wall to the north of his groove [FIGURES 2,7], is a damaged scene, which initially showed Ramesses [Facing North] standing in the presence of the God Horus. All of the king's figure destroyed except for his feet, and the solar disk above his head.

Hours were seated, and facing south, but all that remains of his figure is the top of his double crown and the pedestal of his throne. Above his crown inscribed: $\longrightarrow$ \$ 1 ind $n w$ it $f$ «Horus the Avenger of his Father»

Between Horus and Ramesses are four vertical lines of inscription. They are badly damaged, but their remaining signs read: $\downarrow$

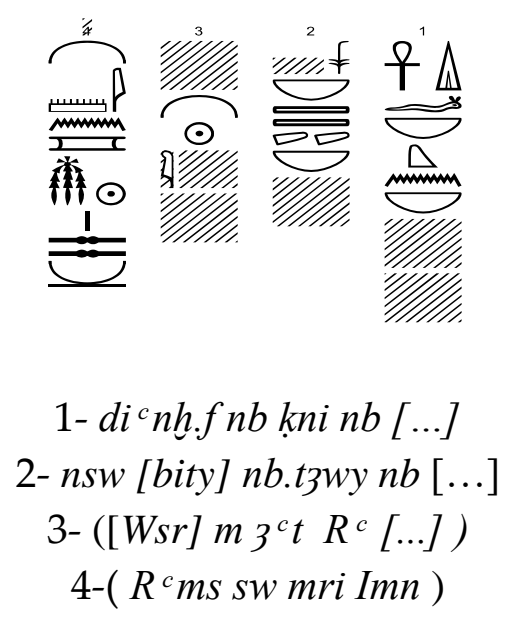

(1)[...] he gives all life, all strength, all [...]

(2) The king of upper [and Lower Egypt] lord of the two lands, lord of [...]

(3) [...] [Weser]-Maât-Râ [...]

(4) [Ramesses Mery-Amon]" 
The Northernmost groove, [FIGURES 2,9] measure the same as its fellow and is also un inscribed. On its southern side [FIGURES 2,8] are two vertical rows of inscription, similar to these beside the southern groove, and reading:

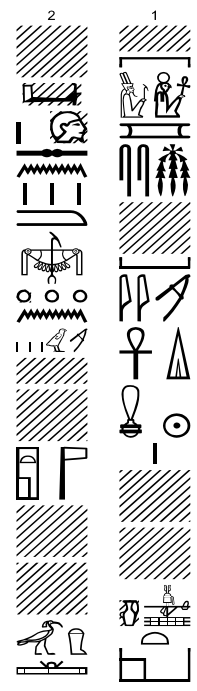

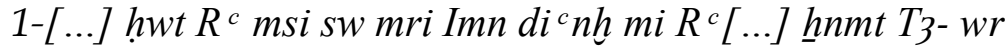 2-tp (w).sn $m \underline{d}^{c} m n$ mrw [...] hwt nt $\underline{t}[$ [...] t3 3 ht $t$}

«(1) [...] the "House of Ramesses-Mery-Amon-who is joined to the Abydos Nome, given life, like Ra [...] Associated with the Abydos Nome»

(2) $[\ldots]$ their heads of fine gold, of Meru-wood [...] Temple [...] horizon".

The vertical inscription on the northern side of this groove is destroyed, but at the bottom of the first column are the figures of three Negro captives, kneeling, with their arms bound, and facing north [FIGURES 2,10].

\section{2-The Red Granite Gateway}

The gateway of the second pylon is formed of massive blocks of red granite. The upper parts of jambs are now destroyed, and the lintel is in fragments. The opening of the gateway measures $2.80 \mathrm{~m}$ wide, and each jamb measures $1.5 \mathrm{~m}$ wide, by $1.53 \mathrm{~m}$ deep at the base. The surface of the outer and inner jambs are beautifully sculptured with scenes and inscriptions in sunken relief, which cut on an average of 3.0 to $3.5 \mathrm{~cm}$ deep.

\section{3- The Southern Jamb: [FIGURES 2, 11]}

The southern jamb is preserved to a height of $4.29 \mathrm{~m}$., and its outer side bore a series of scenes, bordered on the side nearest to the opening of the doorway by a single, vertical line of inscription. 
Of the scenes [FIGURE 3] ${ }^{46}$ there preserved the two lowest and the extreme lower edge of a third scene. There were probably originally scenes. Of the damaged upper scene, all that remains are the feet of the king, and the feet and part of a leg of a God. There was a vertical inscription between the God and the king, but of this, only signs 乐我 $d i^{c} n h$ "given life" are preserved.

The top of the middle scene is occupied by the sign $\rightleftharpoons$, below which, Ramesses is shown offering a libation to Osiris Khenty Amentiu. Above the king's head is the solardisk flanked by crowned uraei. In front of the solar - disk is the two cartouches of Ramesses:

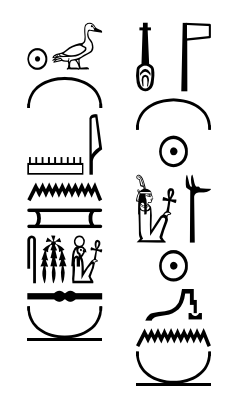

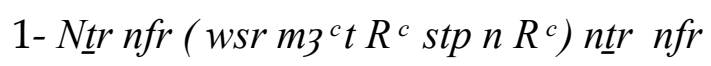
2- s3 $R^{c}\left(R^{c}\right.$ msi sw mry Imn )

1- «The good God, Weser maât- Râ Setep-en- Râ»

2- «The son of Râ, Ramesses Mery-Amon». Behind Ramesses there is a vertical inscription, reading:<smiles>CC=CC=CC=O</smiles>

$S_{3}{ }^{c} n h \underline{d} d d$ w3s «Protection, life, stability, prosperity». Above Osiris are three vertical lines of inscription, reading: $\vdash$

\footnotetext{
${ }^{46}$ MARIETte 1880: Pl.2, c.
} 


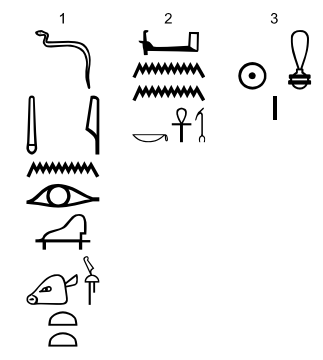

1-d $\mathrm{d} d \mathrm{mdw}$ in Wsir Hnti-Imntt

2-di.n. (i) n.k ${ }^{c} n h$ w3s

3-mi $R^{c}$

«(1) Recitation by Osiris Khenty - Amentiu,

(2) I give to you life and prosperity,

(3) like Râ»

The bottom scene is also topped by the sign of heaven. Below it, and facing north, the God Thot is seated, and with his reed pen appears to be writing the vertical inscription on the edge of the jamb, he holds a palette in his left hand. Behind Thot stands his attendant spirit, a male figure. He carries a water pot in his raised right hand, above which is inscribed: $\infty$ iri "writing ", and a writing outfit in his hand. Above these two figures are eight short, vertical lines of inscription reading:

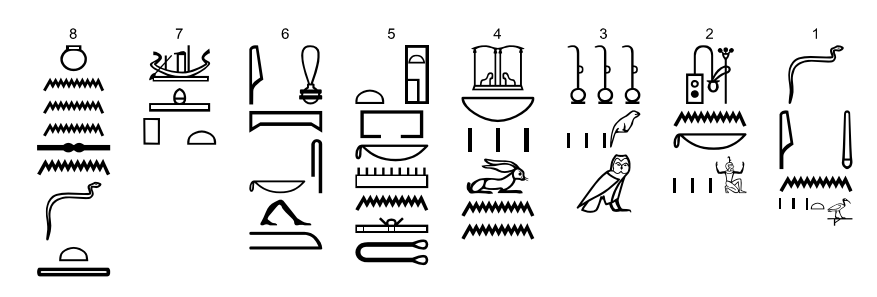

(1) dd mdw in Dhhwty (2) sš.i n.k ḥh (3) rnpwt ḥfnw m (4) ḥb.w wnn (5) ḥwt.k mn.t (6) mi pt š̌m (7) wiz htp (8) nwn .sn $\underline{d} t$

«(1) Words spoken by Thot, (2) I write to you millions (3) of years, hundreds of thousands of (4) jubilees, existing (5) your temple fixed(6) like heaven, the divine form (7) of the sacred boat resting (8) upon its water for eternity»

The vertical text down the edge of the jamb reads as follows: 


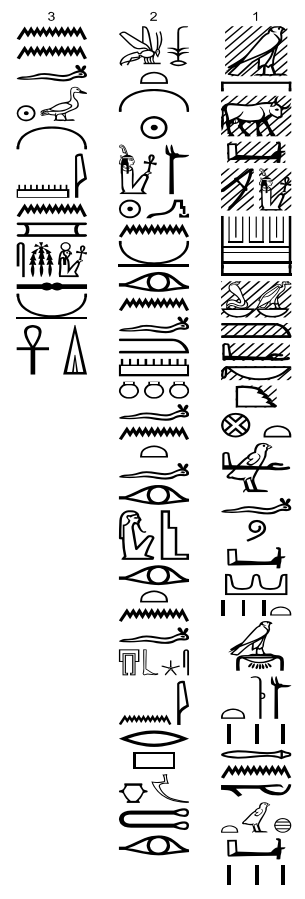

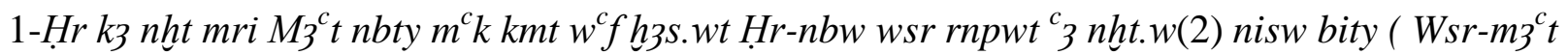
$\left.R^{c}-s t p-n-R^{c}\right)$ ir n.f mnw f $n$ it.f wsir ir.t n.f sb3 (m) inr m3t iri (3) nn.f s3 $R^{c}\left(R^{c}-m s i-s w\right.$ mriImn) $d i^{c} n h$

«(1) Horus the strong bull, beloved of Maât, who belongs to the two ladies, protector of Egypt. Curbing the foreign lands, Gold Horus rich in years, great in victories, (2) the king of upper and lower Egypt, Weser-maât-Râ Setep en Râ, He has made as his monument for his father Osiris, making for him a doorway of granite a stone, being what (was) made (3)for him by the son of Râ-Ramesses Mery-Amon, a «given life».

Below this and the three scenes are four horizontal lines of inscription. The three upper ones are the original text of Ramesses II, but the fourth was added by his son, Merenptah. These lines read as follows:

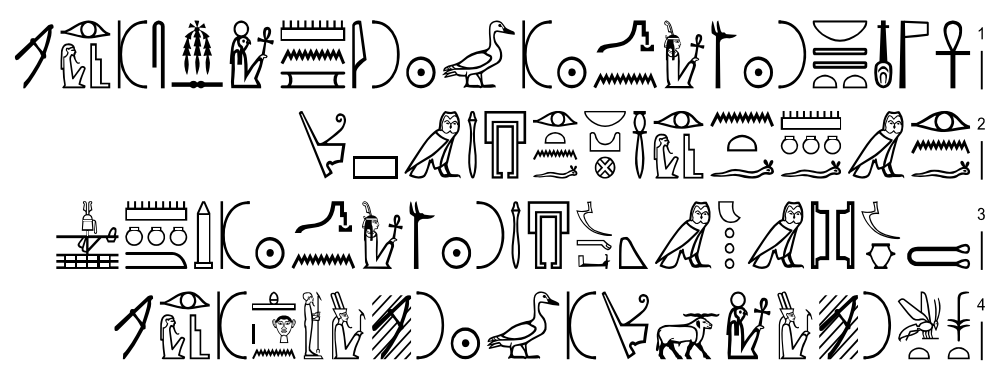

(1) ${ }^{c} n h$ h $\operatorname{tr} n$ fr $n b$ tzwwy $\left(W s r m 3^{c} t R^{c}\right.$ stp $\left.n R^{c}\right) s z R^{c}\left(R^{c} m s\right.$-ss mri Imn)| mri Wsir

(2) ir n.f mnw.fn it.f Wsir $n b 3 b \underline{d} w$ ir.t $n . f s b_{3}{ }^{c} 3 m$ inr $n$

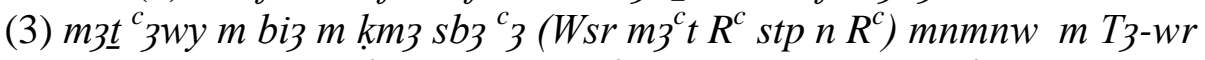

(4) $n s w$ bity (b3 $n R^{c}$ mri imn) $s_{3} R^{c}$ (mri $n$ pth htp hr m3 ${ }^{c}$ t) mri Wsir

(1) Viva /(Long) Life the good god, lord of the two lands, Weser maât Râ, the son of Râ, Ramesses Mery Amon, beloved of Osiris.

(2) He has made it as his monument for his father Osiris, lord of Abydos, making for him a great doorway of stone. 
(3) Granite, its two-door leaves of copper, with engraved figures ${ }^{47}$ Great door of wesermaât Râ who established monuments in the Abydos Nome

(4) The king of upper and lower Egypt ,Ba en Râ Mery Amon, the son of Râ Merenptah Hetep hẹer maât, beloved of Osiris.

\section{4- The Southern Inner Jamb [FIGURES 2, 12]}

The Southern inner jamb bears a large cartouche of Ramesses II, its upper part is destroyed, and the remainder reads: $\downarrow$

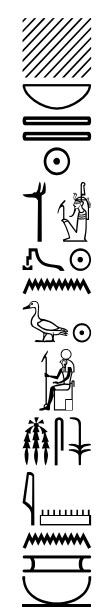

[...] nb t3wy Wsr $m^{c}{ }^{c} t R^{c}$ stp $n R^{c} s 3 R^{c} R^{c} m s i-s w$ mri Imn

«[.... Lord of the two lands, Weser- maât-Râ Setep en Râa, the son of Râ Ramesses Mery

Amon»

Below is a single horizontal line of inscription, added by Merenptah: —

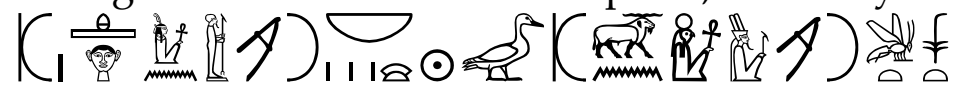

Nsw bity $n b$ t3wy (b3 $n R^{c}$ mri Imn) sz $R^{c} n b$ hcw (mri $n$ Pth htp hr m3 ${ }^{c}$ t)

«The king of upper and lower Egypt, lord of the two lands, Ba en Râ Mery Amon, the son of Râ, lord of crowns, MerenptḤ Ḥotep ḥer Maât»

\section{5- The Northern Jamb [FIGURES 2, 13]}

The northern jamb is less well-preserved than the southern one. On its outer face, only the lowest of scenes is preserved. It represented the Goddess Seshat seated and facing south, like Thot on the southern jamb. Below this scene, there are four horizontal lines of inscription, they are exactly similar to those in the same place on the southern jamb. The long, vertical inscription is also identical to that on the southern jamb.

\section{6-The Northern Inner Jamb [ FIGURES 2, 14]}

The northern inner jamb bears an identical decoration to the southern one, but it is less well-preserved.

${ }^{47}$ Or [ Fashioned with engraving] 


\section{7-The Lintel}

The massive lintel, which now measures about $2.60 \mathrm{~m}$. high, was found in fragments. At the top was the sign of heaven, and below it, a large winged disk, flanked by crowed uraei. Blow the disk, there were large cartouches of Ramesses II overhead with horizontal ram's horns, a disk, and two plumes.

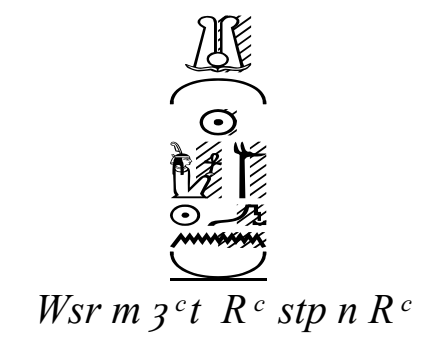

Weser-maât- Râ step n Râ

To the south is vertical inscription reading:

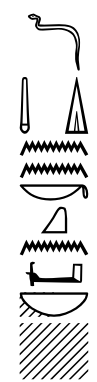

$\underline{d} d m d w$ di.n.(i) $n . k$ knt $n b[\ldots]$

«Recitation: I give to you all strength $[\ldots] »$

In the upper southern corner is the commencement of a vertical, reading:

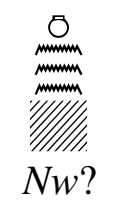

\section{8 -The Northern Tower of the Pylon}

This tower has the same measurements as the southern one, but is preserved to a maximum height of only $1.60 \mathrm{~m}$. Immediately to the north of the northern jamb of the red granite doorway [FIGURES 2, 15] is a damaged representation of Ramesses II (facing south). In front of him is a vertical line of inscription, reading: $\vdash$

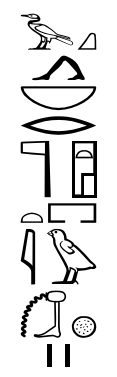

$$
{ }^{C} k n b r h w t n t r i w w^{C} b s p-s n
$$

«All who enter the temple are to be purified twice». 
On the southern side of the first groove [FIGURE 2, 16] are the lower parts of two vertical lines of inscription. Reading

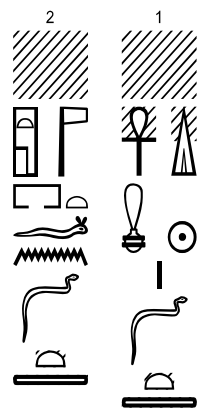

(1)[...] di ${ }^{c} n h$ mi $R^{c} \underline{d} t(2)[\ldots]$ hwt $n \underline{t} r . f n \underline{d} t$

(1)[...] given life like Ra forever (2) [...] his temple of eternity"

The first groove [FIGURES 2, 17] of pylon has the same measurements as those in the southern tower, and like them is undecorated. On the northern side of the first groove [FIGURES 2, 18] are also two vertical inscriptions, reading: $\downarrow$

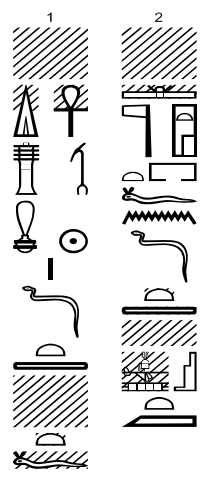

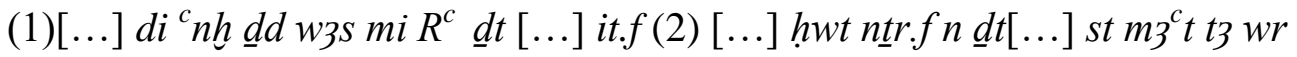

(1)«[...] given life, stability, like Râ forever (2) [...] his temple eternity [...] the place of truth in the Abydos Nome».

On the southern side of the second groove [FIGURE 2, 20] are the ends of two vertical lines of inscription, reading:

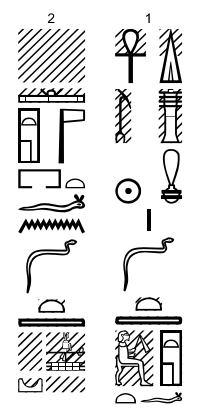

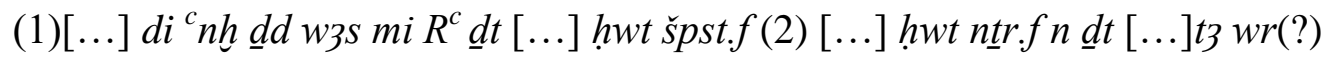

(1)«[...] given life, stability, likes Râ forever (in) his august temple (2) [...] his temple eternity [...] the place of truth in the Abydos Nome». 
The northern groove [FIGURES 2, 21] is als[FIGURES 2, 22] o undecorated, of the vertical inscriptions on the northern side of this groove (Fig.2, 22) only the following signs remain: $\vdash$

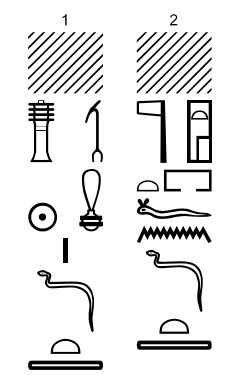

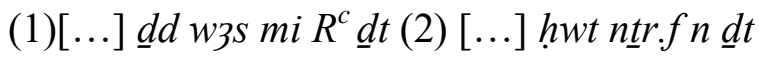

$(1) \ll[\ldots]$ stability, likes Râ forever $(2)[\ldots]$ his temple eternity»

Following this inscription is scene is a scene showing Ramesses receiving two groups of Asiatic prisoners of war. Behind the king stands his ka, personified as a small figure of a bearded man, upon his head is the ka-symbol $\mathcal{\cup}$. Between the king and his $\mathrm{ka}$, the royal srh, the upper part of which is destroyed, it reads

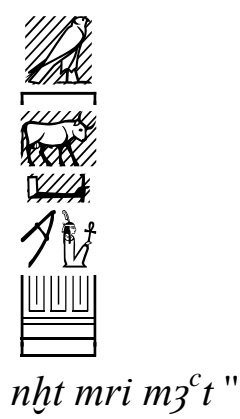

$\left[\begin{array}{ll}H r & k 3\end{array}\right]$ hht $\mathrm{mri} \mathrm{m}^{c}{ }^{\prime \prime}$

[Horus the strong Bull] beloved"

In front of the king are two registers, separated from each other by a horizontal inscription [FIGURES 2, 24]. In each register, a Nile god, carrying the w3s-scepter, leads a band of sixteen Asiatic prisoners of war. The upper register is badly damaged. The horizontal inscription dividing the two registers read as follows:

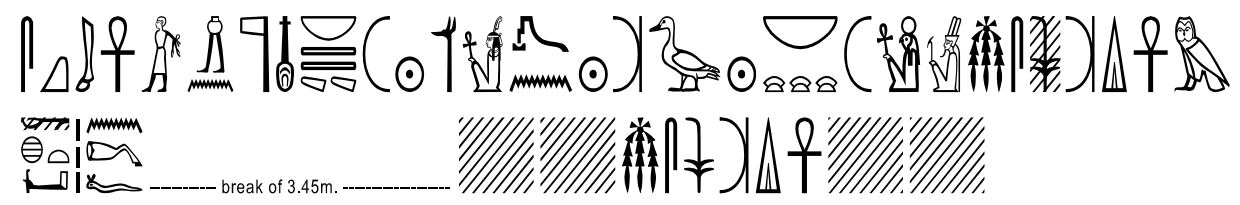

sḳ ${ }^{c} n h$ in $n$ ntr $n f r n b$ tzwy $\left(W s r m 3^{c} t R^{c}\right.$ stp $\left.n R^{c}\right) s_{3} R^{c} n b h^{c} w\left(R^{c}\right.$ msi-sw mri Imn) di ${ }^{c} n h m$ nht.w $n$ hpš.f $[\ldots]([\ldots] m s i-s w[\ldots]) d i^{c} n h[\ldots]$

«Living prisoners brought by the good god, lord of the two lands, Weser Maât Râ Setep en Râ, the son of Ra, lord of crowns Diademes Ramesses Mery Amon, given life, by the victories of his scimitar $[\ldots][\ldots]$ messes $[\ldots]$ given life» 
At the end of the scene [FIGURES 2, 25] is a badly damaged vertical inscription of which only the following signs remain: $\overrightarrow{ }$

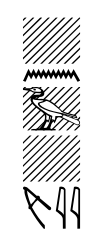

Below are three horizontal lines of inscription, but of these, only the sign $\mathbb{E}$ can be distinguished. Parts of these lines were never completed.

\section{III-CONCLUSION}

From the previous discussion, it is clear that the $2^{\text {nd }}$ pylon of Ramesses II temple at Abydos is the original outer pylon. But, perhaps in anticipation of the Heb- sed feast, he added another court and another pylon in front of last mentioned one.

The subject of the inscriptions and scenes on the $2^{\text {nd }}$ pylon consists of:

Title and epithets of Ramesses II.

Texts concerned with dedication the temple for Osiris, the lord of Abydos.

Names of southern countries which Ramesses II claims to conquer, and Asian prisoners of war. It may be noted that the names of the south countries were inscribed in the southern tower, while the Asiatic prisoners were inscribed in the southern tower.

The traditional decoration for the dais of a king's throne, which was executed with the figure of a walking lion.

The materials in which the masts were made and some inscriptions concerning his son, king Merenptah.

\section{ACKNOWLEDGMENT}

I'm very grateful to Prof. Dr. / cAbd El Hamid Zayed Rahemahu Allah for providing me with hieroglyphic texts which he had made during the period in which he held the post of Chief Inspector for the antiquities of Middle Egypt and his kind assistance. 


\section{Festschrift of Professor Ali Radwan [1941-2020]}

\section{BIBLIOGRAPHY}

BAKR, M.: Tāryih al-Sūdān al-qadìm, Cairo (Makatbat al- 'Anglo al-Mișrīya) 1998.

BREASTED, J.H.: Ancient Records of Egypt: Historical Documents from the Earliest Times to the Persian Conquest, vols.2\&3, Chicago (University of Chicago Press) 1906.

BRUGSCH, H.: Recueil de Monuments Égyptiens, I, Leipzig (Hinrichs; Paris: Franck) 1862.

DARESSY, G.: «Les Temples d'Abydos: supplément à la publication de Mariette», Rec Trav 21, 1899, 1-8.

ERMAN, A. \& GRAPOW (eds.), H.: Wörterbuch der ägyptischen Sprache. 5 vols. Leipzig (Akademie Verlag) 1971.

Gardiner, A. H.: Ancient Egyptian Onomastica, vol.1, Oxford (University Press) 1947.

GARDINER, A. H.:Dictionnaire des noms géographiques contenus dans les textes hiéroglyphiques, vols 1 \& 2, Le Caire (Société Royale de Géographie d'Égypte) 1925.

GARDINER, A. H.::: Dictionnaire des noms géographiques contenus dans les textes hiéroglyphiques, vol.3, Le Caire (Société Royale de Géographie d'Égypte) 1926.

GARDINER, A. H.: Dictionnaire des noms géographiques contenus dans les textes hiéroglyphiques, vol.4, Le Caire (Société Royale de Géographie d'Égypte) 1927.

GARDINER, A. H.: Dictionnaire des noms géographiques contenus dans les textes hiéroglyphiques, vol.5, Le Caire (Société Royale de Géographie d'Égypte) 1928.

GARDINER, A. H.: Dictionnaire des noms géographiques contenus dans les Textes hiéroglyphiques, vol.6, Le Caire (Société Royale de Géographie d'Égypte) 1929.

GOELET, O.\& ISKANDER, S: «The Epigraphic Record in the Temple of Ramesses II at Abydos, Preliminary Report», JARCE 48, 2012, 143-183.

GRIFFITH, F. Li: «Meroitic Studies III», JEA 4, 1917, 21-27.

KEES, H.: Ancient Egypt. A Cultural Topography, London (Faber \& Faber) 1961.

Kitchen, K.A.: Ramesside Inscriptions. Translated \& Annotated II, Oxford (B.H. Blackwell Ltd) 1996.

Kitchen, K.A.: Ramesside Inscriptions. Translated \& Annotated Notes \& Comments, vol.2, Oxford (B.H. Blackwell Ltd) 1999.

LEFEBVRE, G.: «Une chapelle de Ramsès II à Abydos», ASAE 7, 1906, 213-220.

LEPSIUS, R.: Denkmäler aus Ägypten und Äthiopien, Band vol.1, Leipzig (Hinrichs) 1897.

MARIETTE, A.: Abydos: Description des fouilles exécutées sur l'emplacement de cette ville, vol.1, Paris (Franck; Imprimerie Nationale) 1869.

MARIETTE, A.: Abydos: Description des fouilles exécutées sur l'emplacement de cette Ville, vol.2, Paris (Franck; Imprimerie Nationale) 1880.

Mariette, A.: Fouilles exécutées en Égypte, en Nubie et au Soudan, vol.2, Paris (Franck) 1867.

MONTET, P.: Géographie de l'Égypte Ancienne, vol.2, Paris (Librairie C. Klincksieck) 1961.

O'CONNOR \& DAVID B.: Abydos: Egypt's First Pharaohs and the Cult of Osiris, London, New York (Thames \& Hudson) 2009.

PORTER, B.\& L. B. MOSS, R.L.B.: Topographical Bibliography of Ancient Egyptian Hieroglyphic Texts, Reliefs and Paintings, vol.6, Upper Egypt: Chief Temples, Oxford, (Griffith Institute \& Ashmolean Museum) 1976. 
Ahmed Amin Selim: the Inscriptions of the Second Pylon of Ramesses II at Abydos

SELIM.A.: «The Inscriptions of the Second Pylon of Ramesses II at Abydos», BFAP, Alexandria, 1991-1992, 2-25.

SETHE,K.: Urkunden der 18. Dynastie. Vierter Band, bearbeitet von Kurt Sethe. Historisdhbiographische Urkunden, (Akademie-Verlag in Zusammen arbeit mit der Akademischen Druckund Verlagsanstalt Graz) 1961.

ZAYED, cABD EL-HAMID: «The Inscriptions on the Exterior of the Southern Wall of the Temple of Ramesses II at Abydos», ASAE 67, 1988, 79-114.

ZIBELIUS, K.: Afrikanische Orts und Völkernamen in hieroglyphischen und hieratischen Texten, Wiesbaden (Ludwig Reichert Verlag) 1972. 


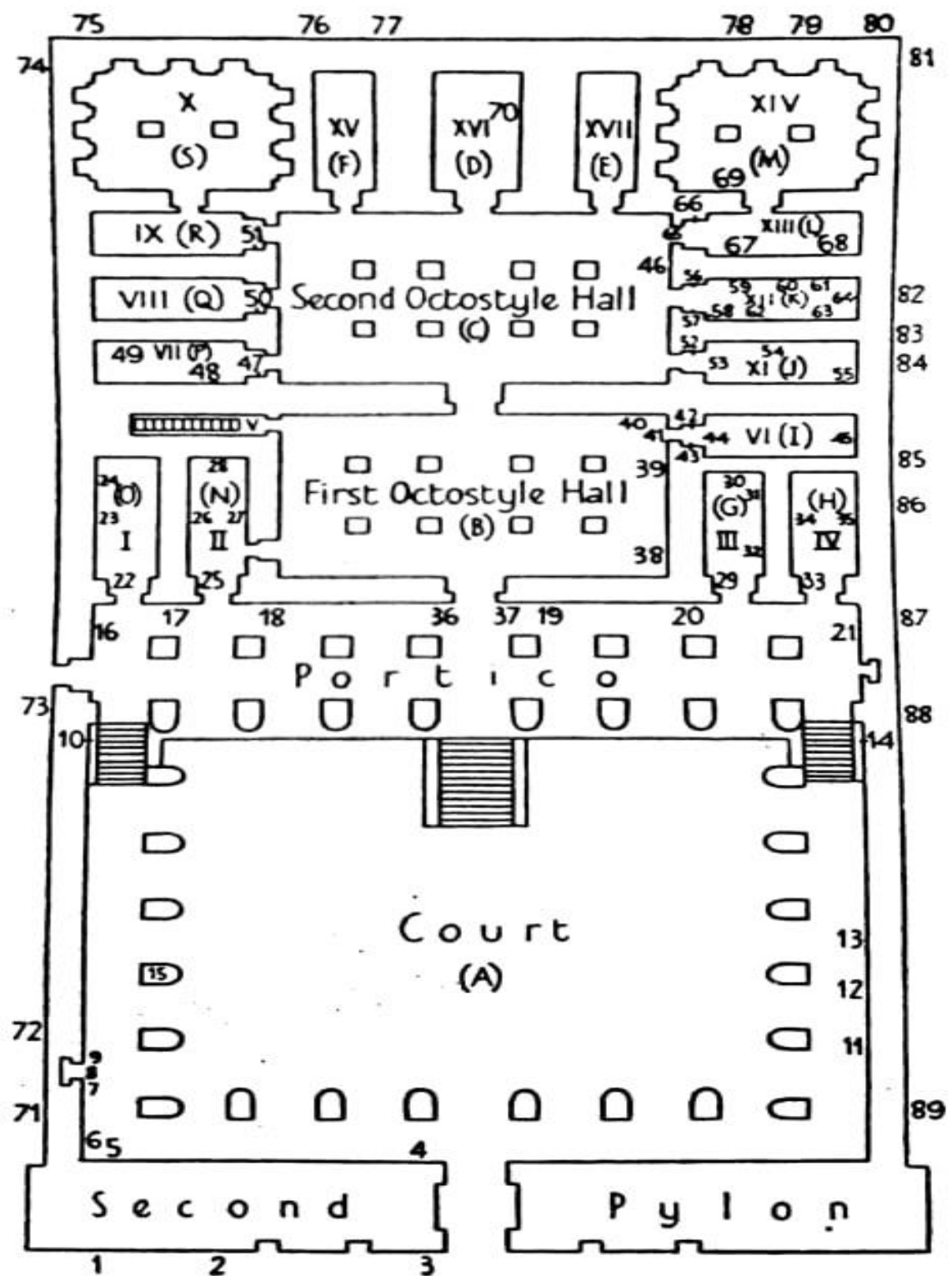

[FIGURE 1 / a]: The Temple of Ramesses II at Abydos PORTER \& MOSS 1976: vol.6: 32 


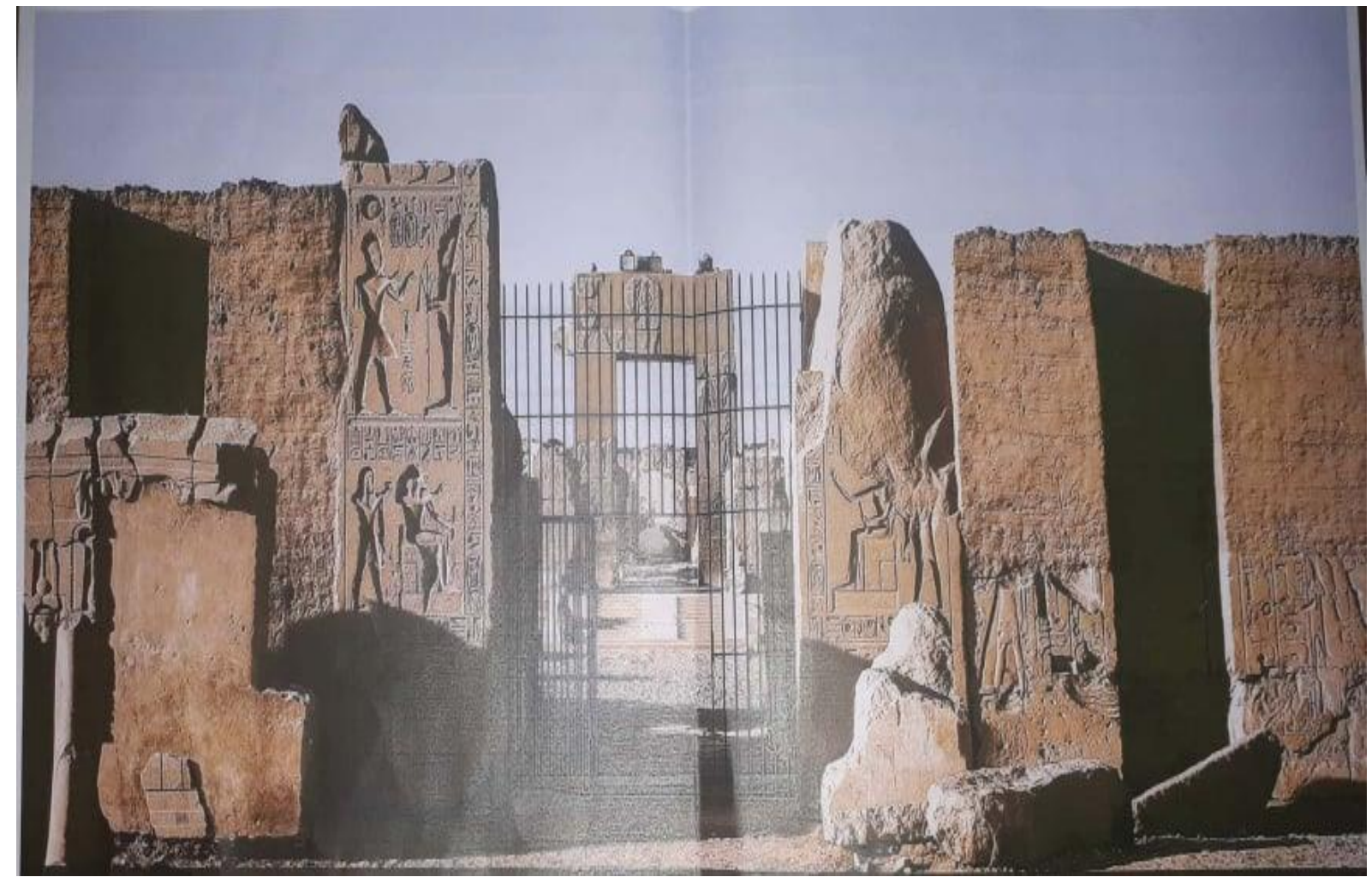

[FIGURE 1 / b] The Second Pylon of the temple of Ramesses II

GOELET \& ISKANDER 2012: 143-183.
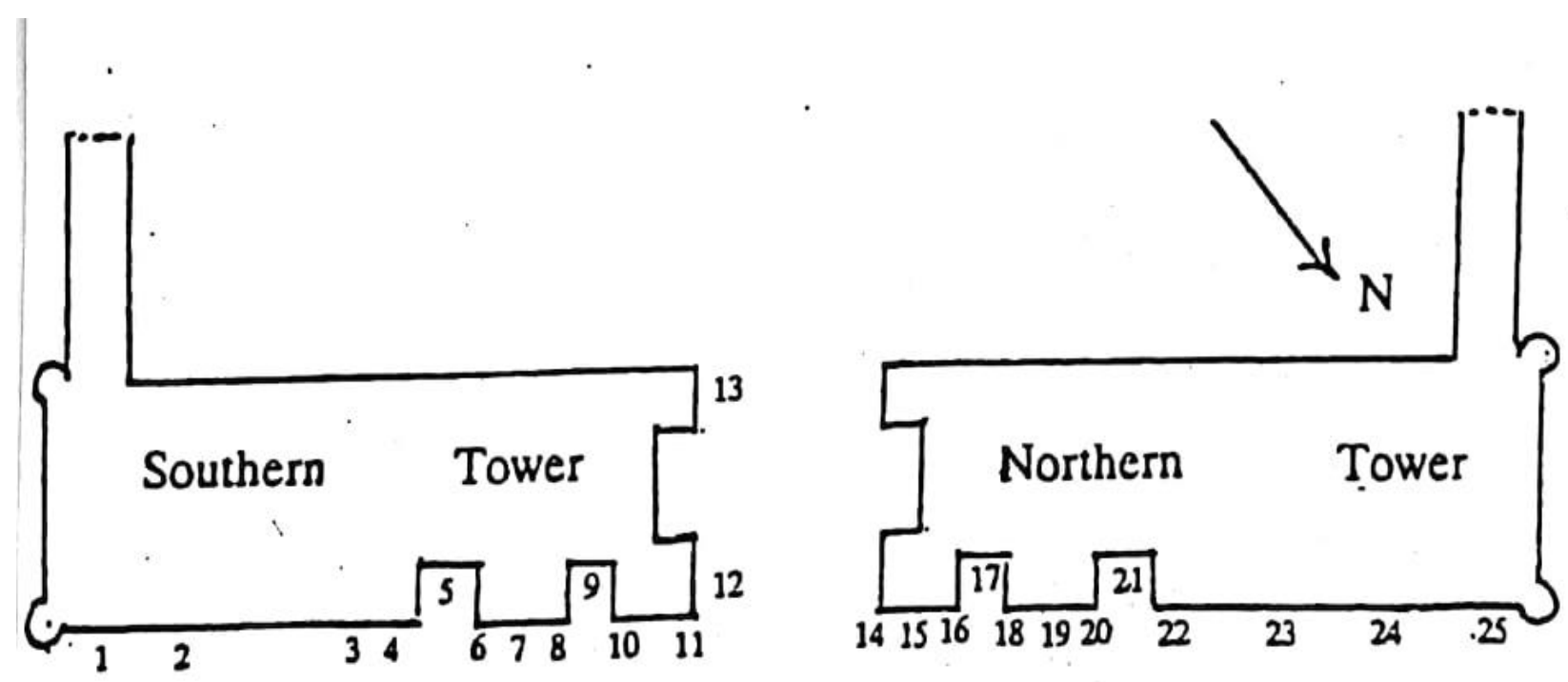

[FIGURE 2]: The Second Pylon. 


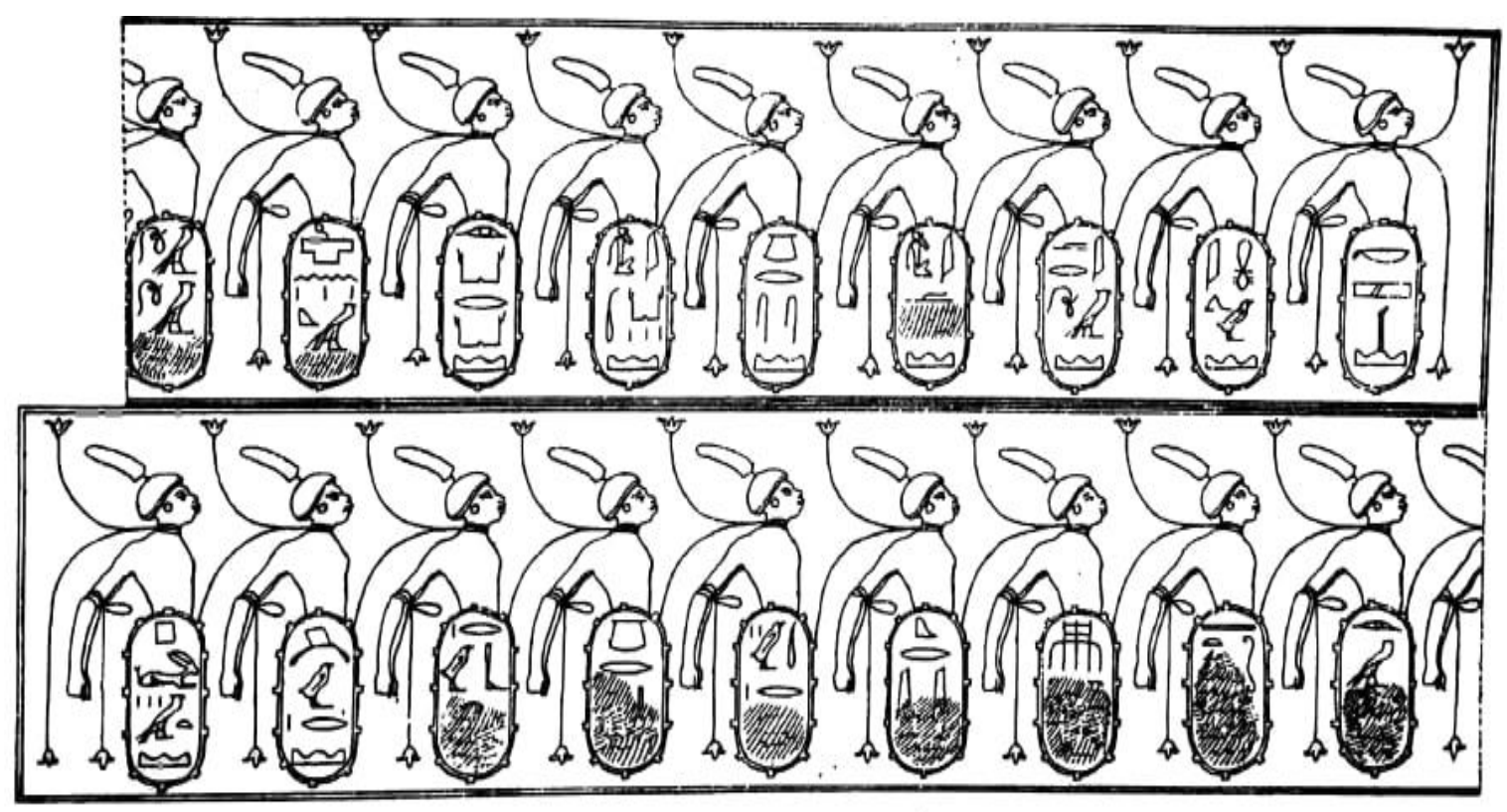

[FIGURE 3]: The name of southern countries. LEPSIUS 1897: PL.3.

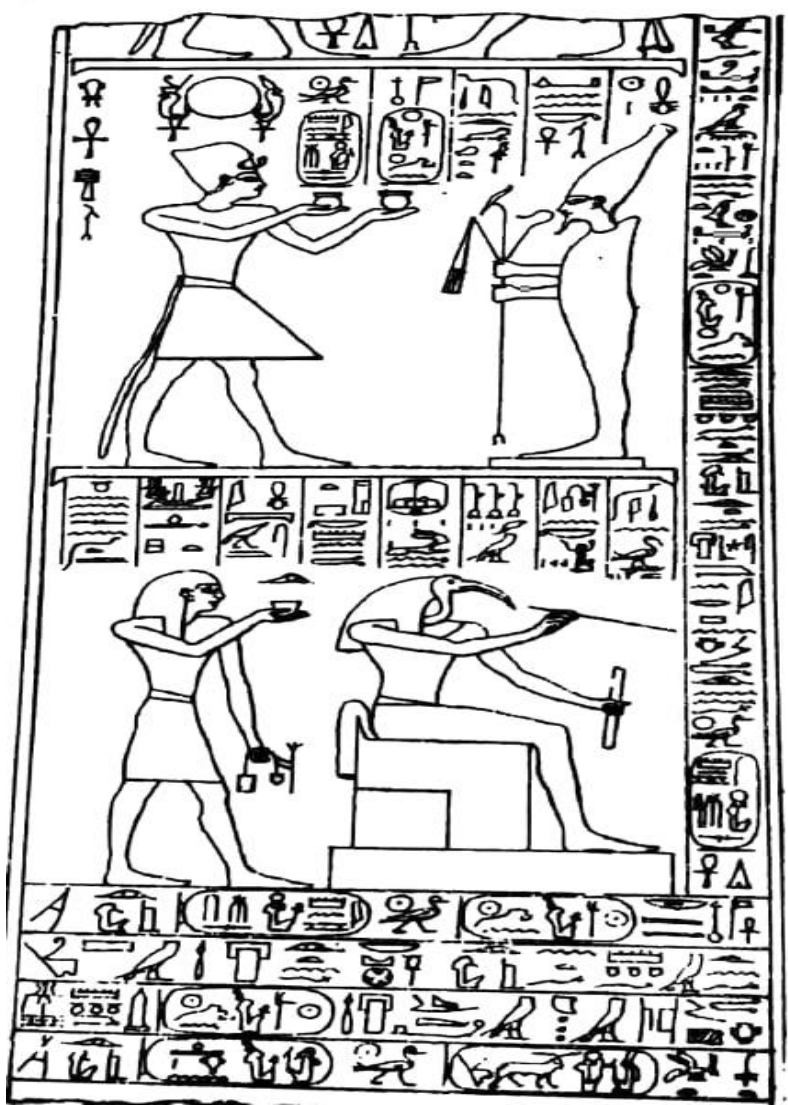

[FIGURE 4]: The Southern Jamb. LEPSIUS 1897: PL.2. 